\title{
Embodied energy in thermal energy storage (TES) systems for high temperature applications
}

\author{
Laia Miró ${ }^{1}$, Eduard Oró ${ }^{1, *}$, Dieter Boer ${ }^{2}$, Luisa F. Cabeza ${ }^{1}$ \\ ${ }^{1}$ GREA Innovació concurrent, Universitat de Lleida, Edifici CREA, Pere de Cabrera s/n, 25001 \\ Lleida (Spain). Phone: +34-973003576, Fax: +34-973003575, e-mail: Icabeza@diei.udl.cat \\ 2 Department of Mechanical Engineering, Universitat Rovira i Virgili, Av. Països Catalans 26, \\ 43007 Tarragona (Spain). Phone: +34-977559631, Fax: +34-977559691, e-mail: \\ dieter.boer@urv.cat
}

* Present address: Catalonia Institute for Energy Research, IREC. Jardins de les Dones de Negre 1, 08930, Sant Adrià de Besòs, (Barcelona), Spain; email: eoro@irec.cat; tel: +34 933562615

\begin{abstract}
Currently, there is an increasing interest in concentrated solar power (CSP) plants as alternative to produce renewable electricity at large scale by using mirrors to concentrate the solar energy and to convert it into high temperature heat. These facilities can be combined with thermal energy storage (TES) systems, which are, nowadays, one of the most feasible solutions in facing the challenge of the intermittent energy supply and demand. However, they are still in research process and, for that, there is a lack of environmental impact studies of these TES systems complementing solar plants. This paper accounts the environmental impact of three TES systems used nowadays in high temperature applications for CSP plants: first, a system which stores sensible heat in high temperature concrete; second, a system storing sensible heat in molten salts; and third, another system with molten salts but storing latent heat. All the systems are normalized in order to be comparable between them due to its initial storage capacity difference. The environmental impact is accounted by calculating the amount of embodied energy in the components of the different TES systems. Notice that embodied energy refers to the total energy inputs required to make a component. Between the three systems, the sensible heat system using concrete as storage material is the one with less environmental impact while the molten salts and PCM have a higher value of embodied energy, mainly due to the nitrate mixture used as storage material. Finally, advantages and disadvantages of the method proposed used are discussed.
\end{abstract}

Keywords: embodied energy; environmental impact; high temperature thermal energy storage (TES) systems 


\section{INTRODUCTION}

Concentrated solar power (CSP) plants are under development and study by many researchers and companies over the world. The main problem of these renewable plants is the mismatch between the solar energy and the energy demand. It is well known that the addition of thermal energy storage (TES) systems provides the benefit of taking an intermittent energy source and converting it to a constant power source, it can shift times of power generation to better match times of consumer demand [1]. Therefore it is a suitable technology to be implemented in the current CSP plants. Medrano et al. [2] presented a summary of different technologies used in solar power plants with TES systems existing in the world with more than 25 case studies. Recently, Whitaker et al. [3] compared a power tower CSP with a two-tank storage system versus a thermocline design. Moreover, Gil et al. [4] created a list of the materials used in high temperature TES applications divided into sensible heat, phase change (PCM), and chemical heat materials and as well as an own new classification of the storage systems dividing it in active and passive storages.

The application of TES systems in the facilities represents the addition of building and storage materials to the system which can have a significant environmental impact depending on their nature. Therefore, when selecting a material or designing a facility it is also important to look at the environmental impact that the product or service has over its entire life cycle. This fact, linked to the nowadays trend of more energy efficient processes, highlights the importance of calculating the environmental impact. Moreover, there are European directives such as 2011/2/EU which concludes the need of taking into account, in public and in private projects, the effects of these impacts on the environment. These impacts can be analysed through a wide range of methods depending on the parameter you want to focus: life cycle assessment (LCA), global warming, ecological footprint, embodied energy, energy analysis, etc. The environmental studies of the inclusion of storage materials in building applications is nowadays under interest, de Gracia et al. [5] used LCA to analyse this impact concluding that the addition of an storage material, in this case a PCM, does not produce a significant variation of global impact results because the impact savings achieved are balanced with the manufacturing impact of the added materials. In high temperature applications, Oró et al. [6] studied, also using LCA methodology, different hypothetical scenarios to point out the differences between three TES systems for CSP showing that the system based on solid media presents the lowest environmental impact per kWh stored of all the systems compared. Whitaker et al. [3] accounted the GHG emissions, water consumption and cumulative energy demand (CED) for a power tower CSP plant with seven design alternatives. The same parameters are analysed by Burkhardt et al. [7] in a parabolic trough CSP plant varying four design alternatives. In addition, the relationship between embodied energy and embodied $\mathrm{CO}_{2}$ was defined by Cabeza et al. [8], 
they also concluded that embodied energy is difficult to quantify and that since there is no generally accepted methodology for its measurement or calculation, today's data disagree between authors and studies.

In this paper, embodied energy is used to calculate the environmental impact. Moreover, it is chosen due to its versatility and its easy interpretation for a preliminary analysis of a system. Different embodied energy definitions can be found in the literature, as an example, in Alwood et al. [9] is defined as the total energy inputs required to make a component. All the definitions coincide in accounting the energy used through the entire production chain but there is no agreement in the analysis boundaries: some of them consider also the transport from the industry to the application, while others consider the disposal of the material or the percentage of recycled material in the production process. The main advantages of this type of studies is that they can be developed during the design phase of a project, which is also recommended by the European Directive 2011/92/EU, and small changes in the selection of the type or quantity of the materials can be easily analyzed environmentally. Moreover, the embodied energy associated to a facility can be easily translated into its $\mathrm{CO}_{2}$ embodied which is another largely used environmental indicator. Therefore there is a lack of data for the different components of a system in the literature or databases to perform an exact analysis and, also, most of them do not include the specification (boundaries, etc.) of the data. Here, the embodied energy of the components of three different systems using TES (solid system, molten salts system and phase change materials (PCM) system) for CSP applications has been analysed to compare their environmental impact during their manufacturing, operation life and disposal.

\section{CASES STUDIED}

In this study, three different TES systems have been analysed to be implemented in CSP plants, two systems using sensible heat materials such as molten salts and concrete and a system using a latent heat material. The systems, which are evaluated, are:

- Solid system: sensible heat is stored in this system using high temperature concrete as storage material [10].

- Molten salts system: heat is stored in liquid media by sensible heat; using molten salts based on a mixture of sodium nitrate $\left(\mathrm{NaNO}_{3}\right)$ and potassium nitrate $\left(\mathrm{KNO}_{3}\right)$ [11].

- PCM system: latent heat is stored using the same molten salts [12] described in the previous system $\left(\mathrm{NaNO}_{3}\right.$ and $\left.\mathrm{KNO}_{3}\right)$ but with different component percentage.

Table 1 lists the main characteristics of the three systems such as storage capacity, storage material, amount of storage material, and storage capacity ratio. The storage capacity ratio is 
defined as the ratio between the storage capacity and the amount of storage material. Notice that, depending on the TES system design, the storage capacity ratio is different even when considering similar storage materials.

In this analysis, the working conditions (temperature gradient, thermal characteristics of the TES materials, etc.) are not considered because it is only considered the quantity of the components that form the TES system and their embodied energy.

The main part of these facilities is the storage material. For that reason, another interesting parameter when characterizing these facilities is the price per tonne of this material. It can be seen that solar salts are significantly more expensive $(375 \%)$ than the high temperature concrete (Table 1). The cost of the storage material is directly proportional to the complexity of its fabrication process.

First, the solid system is composed by a tubular heat exchanger which is integrated into the storage material, which is high temperature concrete (Figure 1). The heat exchanger is based on 36 tubes of steel with a nominal diameter of $21 \mathrm{~mm}$. These are distributed in a squared arrangement of $6 \times 6$ tubes with a separation of $80 \mathrm{~mm}$. The TES system consists of two modules with dimensions of $0.48 \times 0.48 \times 23 \mathrm{~m}$. This TES system has a storage capacity of about $350 \mathrm{kWh}$ and can operate with maximum temperatures of $390^{\circ} \mathrm{C}$. Table 2 lists the quantity of each component of this system and its related embodied energy.

Second, the configuration of the molten salts system consists in two storage tanks where the

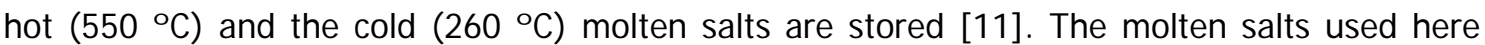
were $60 \mathrm{wt} \% \mathrm{NaNO}_{3}$ and $40 \mathrm{wt} \% \mathrm{KNO}_{3}$ which are typically used in CSP plants. Figure 2 shows the storage system of a real CSP plant. The thermal capacity of the storage system is $600 \mathrm{MWh}$, which corresponds to about $5500 \mathrm{t}$ of molten salts with a thermal gradient between the two tanks of $260 \stackrel{\circ}{ }$. Table 3 lists the quantity of components used in the molten salts storage system and the CED value for each component.

Finally, the PCM TES system consists of storage tank filled with PCM (Figure 3). The tank used consists of a bundle of 36 parallel tubes comprised by six pipes arranged in six passes with fins in order to enhance the heat transfer between the heat transfer fluid (HTF) and the PCM. The PCM used was $54 \mathrm{wt} \% \mathrm{KNO}_{3} 46 \mathrm{wt} \% \mathrm{NaNO}_{3}$ eutectic mixture which melts at $221 \stackrel{\circ}{\circ} \mathrm{C}$. The total amount of PCM used was $2100 \mathrm{~kg}$ being the storage capacity of the system of $600 \mathrm{MWh}$. Table 4 lists the quantity of the components and the CED value of the PCM storage system. 


\section{METHODOLOGY}

In order to account the embodied energy of these three TES systems, a method and a database should be chosen. The parameters that have to be taken into account are the suitability of the database with the components to be studied, the regional validity of the data, and the boundaries of the collected data. For this study, the calculation of embodied energy has considered the energy of the extraction, manufacture, disposal, and transport.

Nowadays materials embodied energy data can be found in some databases, but they are mainly focused only in building materials. As an example, the University of Bath [16] has created an inventory of embodied energy and carbon coefficients for building materials with over 1700 records named Inventory of carbon \& energy (ICE). Its regional validity is the British Isles considering estimation from the typical fuel mix in the relevant UK industries. Moreover, Granta commercializes a software application called CES Selector which has materials property database (nearly 3500 records) and the possibility to plot results [17]. On the other hand, Ecolnvent database provides more than 4000 material records based on industrial data from central Europe [18].

Before choosing a database it's important to know which its regional validity is and if it agrees with the location of your building or facility under study. For that, Ecolnvent database has been chosen. This database provides the needed data to perform environmental analysis that can be useful to determine the impact of the three case studies, among all of them, CED accounts the materials embodied energy. Table 5 lists the components of the three TES systems analysed as well as their corresponding database name, equivalent unit and code number corresponding to Ecoinvent database.

Ecoinvent database lists its methods by impact category, unit and application. In Table 6 some of the environmental methods available in this database are shown. Ecological footprint is measured in square-meters-year and it is defined as the biologically productive land and water that a population requires to produce the resources it consumes and to absorb part of the waste generated by fossil and nuclear fuel consumption. Moreover, the Environmental Design of Industrial Products 2003 (EDIP 2003) method and the Tool for the Reduction and Assessment of Chemical and other environmental Impacts (TRACl) method are composed by different impact categories (ecotoxicity, acidification, eutrophication, global warming, etc.) and, within them, global warming impact category (measured in $\mathrm{kg}$ of $\mathrm{CO}_{2}$ ) could also give an idea of the energy embodied in a material Finally, the cumulative energy demand (CED), which is measured in MJ. It considers direct and indirect energy use throughout the life cycle, including the energy consumed during the extraction, manufacturing and disposal of the raw and 
auxiliary materials. This method focuses on the limited access to energy resources in a broader sense than just fossil energy by including all types of energy use. CED considers that all the materials are produced by using different energy sources (depending on the energy mixes). For that, CED can be calculated as the sum of these energy subcategories resources: fossil, nuclear, primary forest, biomass, wind, solar geothermal and water (Eq.1). The data provided by this database is valid for central Europe. Furthermore it has the longest scientific history, the lowest number of environmental interventions required and the lowest data uncertainty involved [19].

$$
E_{C E D}=E_{\text {fossil }}+E_{\text {nuclear }}+E_{\text {primary forest }}+E_{\text {biomass }}+E_{\text {wind }}+E_{\text {solar }}+E_{\text {geothermal }}+E_{\text {water }}
$$

All the methods presented can be applied globally, which means they do not have any geographical limitation. From all the listed methods, CED is chosen for this environmental analysis because it represents the energy embodied in the materials in energy units (MJ).

All the databases agree in the existence of uncertainty in these types of data. It can be due, first, to the different fuel mixes and technologies used in the different industries that manufacture the same material and, second, to the authors providing data with unspecified boundaries, some of them taking into account the transport of the material to the facility, others considering the disposal of the materials or the percentage of recycled products. For that, some databases recommend taking into account a percentage of uncertainty, as an example, Granta database recommends considering a $20 \%$ of uncertainty.

The TES systems analysed in this study are very different in size and in storage capacity (Table 1Table ): the solid and the PCM storages are at pilot plant scale (350 and $100 \mathrm{kWh}$, respectively) while the molten salts system is dimensioned for a real installation (600 MWh). For that reason it is necessary to carry on a normalization process in order to compare results between each other. The base of normalization considered is $600 \mathrm{MWh}$ of storage since it is real application storage system. Therefore, the new quantity of storage material has been calculated using $600 \mathrm{MWh}$ as storage capacity for the solid and PCM storages maintaining the original working temperatures. In order to achieve the same storage capacity than the molten salts system, the solid system needs around 8,733 tons of high temperature concrete and the PCM system needs around 13,677 tons of the nitrates mixture. Then, the rest of the system components have been resized supposing the same length than the original system and taking into account the author's design. 


\section{RESULTS AND DISCUSSION}

Using the CED method with the data from Ecolnvent database, the embodied energy of each component that belongs to a TES system is calculated by multiplying the quantity of the component by its embodied energy. This embodied energy of each component is listed in Table 2 for the solid system, in Table 3 for molten salts system, and in Table 4 for the PCM system. Then, the total embodied energy for the different TES systems is the result of the addition of the different components embodied energy. That results in a total embodied energy in the solid system of $17 \mathrm{TJ}$ while for the molten salts system analysed is $125 \mathrm{TJ}$, and for the PCM is $257 \mathrm{TJ}$ (Figure 4). It can be seen how the more processed and complex is the component, the higher embodied energy it has. Moreover, despite the normalisation, a clear difference between the quantity of storage material in PCM and in molten salts system is shown due to their different design. That is also reflected in Table 1 with different relations of storage capacity in $\mathrm{MWh} / \mathrm{kg}$ : $1.09 \cdot 10^{-4}$ for molten salts system and $4.76 \cdot 10^{-5}$ for PCM system.

However, absolute values could not be enough in order to analyse the systems, therefore, a percentage distribution of the most influencing components for the three of them was calculated. Using this type of representation, the combined influence of both the quantity of material and the component embodied energy value can be seen. Notice that the disposal of each component is also considered in the component embodied energy value. First, Figure 5 shows the distribution of the most influencing components for the sensible heat system. The storage material, in this case, high temperature concrete, has a third part of the total embodied energy of the system ( $28 \%$ ). The structural part of the system, concrete and tube of steel, introduce $72 \%$ of the total embodied energy, among them, steel tubes have the higher influence due to its design: the HTF goes through steel tubes located inside the storage material. The other building and insulating components (metal sheets and rock wool) represent less than $5 \%$ of the total CED and they are not shown.

Similarly, Figure 6 shows the distribution of the embodied energy percentage for the molten salts system. As expected, the storage material $\left(\mathrm{KNO}_{3}, \mathrm{NaNO}_{3}\right)$ is the most significant component in the embodied energy calculation due to their nature, which is about $70 \%$ of the total. It is followed by the firebricks since this configuration presents high amount of firebricks not only as fire protection but for structural purposes. The rest of the components of the system (tubes of steel, metal sheets, etc.) represent less than $10 \%$ of the total embodied energy.

Finally, Figure 7 shows the embodied energy percentage for the components of the latent heat storage system. In this case, $\mathrm{KNO}_{3}$ and $\mathrm{NaNO}_{3}$, which in combination are the PCM used as 
storage material, is the most significant component of the system. Notice that here the PCM has the $85 \%$ impact of the total impact being the key component of the whole system. That indicates that, for PCM systems, it is really important the selection of the storage by itself since in comparison with the embodied energy of the container materials it is really important.

Moreover, considering that in all systems, the materials used in the design can be divided into "storage materials", the material that stores the heat, and "containing materials", the structural, building and insulating materials, Figure 8 shows the influence of them in percentage. Remember that for the solid system, the storage material is high temperature concrete, and for both the PCM and the molten salts the storage material is the nitrate mixture, which has a high embodied energy assigned. Their related disposal has been also taken into account in this comparison. The influence of the containing materials depends on the complexity of the system and mainly to the amount of steel used in them. Results show in the solid system that the storage material contribution to total embodied energy is the lowest (around $30 \%$ ). Besides, in molten salts systems is $70 \%$ and in the PCM system $85 \%$.

The major advantage of applying this method is that it represents an easy and understandable first environmental screening of the system. Also, it allows applying changes into the same system and to see in a fast way if energy savings can be achieved. Moreover, it is a global method, meaning that it can be applied to the entire world. However, this last advantage represents also a big drawback because the energy needed to produce component is different depending on the region, and, this data nowadays is not available. Thus, specific regional data for energy embodied in the different components is needed for an exact and reliable study on embodied energy in different applications.

\section{CONCLUSIONS}

An environmental analysis of three TES systems used in CSP plants is done. For that, different databases regarding environmental methods have been analysed. Between them, Ecolnvent database has been chosen due to the specific data needed for this type of analysis and for its facilities and also due to the agreement between the location of the plants and the validity region of the database. This database provides different environmental indicators, among them, CED method is selected as it represents the embodied energy of different materials. In this method, the embodied energy of each component that belongs to a TES system is calculated by multiplying the amount of each component by its embodied energy. Then, the total embodied energy for the different TES systems is the result of the addition of the different components embodied energy. 
Three TES systems from the literature are analysed. In the first place, a system which stores sensible heat in high temperature concrete, secondly, a system storing sensible heat in molten salts $\left(\mathrm{NaNO}_{3}\right.$ and $\left.\mathrm{KNO}_{3}\right)$ and, finally, another system with molten salts storing latent heat. Due to the different dimensions of these systems, a normalization process has been performed using the base of normalisation of $600 \mathrm{MWh}$ and keeping the same design and original working temperatures.

The highest embodied energy is obtained by the PCM system (257 TJ) followed by the molten salts system (125 TJ) and the solid system, $17 \mathrm{TJ}$, representing the system with the less environmental damage. The highest values achieved in the molten salts and in the PCM systems are due, mainly, to the high embodied energy value of the nitrate mixture. Moreover, these results have been presented using different points of view, first, a general overview of each system and the influence of each component compared to the total TES embodied energy. Second, comparing the components embodied energy contribution depending of their function (if they are containing or storage materials). In this case, solid system has a $30 \%$ of storage material embodied energy influence while molten salts system and PCM system have a similar influence of the storage material in global embodied energy (70\% and $85 \%$, respectively). Disposal of the components has also been considered. In this accounting, the method presented in this paper can be helpful to detect in which components of the system embodied energy savings could be achieved.

In order to perform embodied energy analysis, CED method is a very interesting tool. Its main advantages are that it can be easily developed during the design phase of a project, and small changes in the selection or amounts of the materials can be easily environmentally analyzed. Moreover, the embodied energy in a facility can be easily translate into another environmental indicators, as $\mathrm{CO}_{2}$ embodied. However, its major drawback is that despite the fact that it is a method that can be globally applied, specific regional data is still needed and, nowadays, there is a lack of this information in the available literature. For that, this analysis is only valid for these three systems and as a trend value because a $20 \%$ of uncertainty in the values is defined for these databases. Moreover, embodied energy is mainly available for buildings and not for this type of facilities; few databases include other engineering data. To improve these types of analysis and making them environmentally useful, specific regional data has to be generated. 


\section{Acknowledgements}

The work was partially funded by the Spanish government (project ENE2011-22722). The authors would like to thank the Catalan Government for the quality accreditation given to their research group GREA (2009 SGR 534). The research leading to these results has received funding from the European Union's Seventh Framework Programme (FP7/2007-2013) under grant agreement $n^{\circ}$ PIRSES-GA-2013-610692 (INNOSTORAGE). Eduard Oró would like to thank the University of Lleida for his research fellowship. Laia Miró would like to thank the Spanish Government for her research fellowship (BES-2012-051861).

\section{References}

[1] Powell KM, Edgar TF. Modeling and control of a solar thermal power plant with thermal energy storage. Chem Eng Sci 2012;71:138-145.

[2] Medrano M, Gil A, Martorell I, Potau X, Cabeza LF. State of the art on high-temperature thermal energy storage for power generation.Part 2-Case studies. Renew Sust Energ Rev 2010; 14:56-72.

[3] Whitaker MB, Heath GA, Burkhardt JJ, Turchi CS. Life cycle assessment of a power tower concentrating solar plant and the impacts of key design alternatives. Environ Sci Technol 2013;47:5896-5903.

[4] Gil A, Medrano M, Martorell I, Lázaro A, Dolado P, Zalba B, Cabeza L F. State of the art on high temperature thermal energy storage for power generation. Part 1-Concepts, materials and modellization. Renew Sust Energ Rev 2010;14:31-55.

[5] de Gracia A, Rincón L, Castell A, Jiménez M, Boer D, Medrano M, Cabeza LF. Life Cycle Assessment of the inclusion of phase change materials (PCM) in experimental buildings. Energ Buildings 2010;42:1517-1523.

[6] Oró E, Gil A, de Gracia a, Boer D, Cabeza LF. Comparative life cycle assessment of thermal energy storage systems for solar power plants. Renew Energ 2012;44:166-173.

[7] Burkhardt JJ, Heath GA, Turchi CS. Life cycle assessment of a parabolic trough concentrating solar power plant and the impacts of key design alternatives. Environ Sci Technol 2011;45:2457-2464.

[8] Cabeza LF, Barreneche C, Miró L, Morera J M, Bartoli E, Fernández Al. Low carbon and low embodied energy materials in buildings: a review. Renew Sust Energ Rev 2013;23:536-542.

[9] Alwood JM, Cullen JM. Sustainable materials with both eyes open: Future Buildings, Vehicles, Products and Equipment - Made Efficiently and Made with Less New Material. 2012, UIT Cambridge, Cambridge, UK.

[10] Laing D, Steinmann WD, Tamme R, Richter C. Solid media thermal storage for parabolic trough power plants. Sol Energy 2006;80:1283-9. 
[11] Gabrielli DR, Zamparelli C. Optimal design of a molten salt thermal storage tank for parabolic trough solar power plants. J Sol Energy Eng 2009;131: 04100110-04100120.

[12] Bayón R, Rojas E, Valenzuela L, Zarza E, León J. Analysis of the experimental behaviour of a $100 \mathrm{kWhth}$ latent heat storage system for direct steam generation in solar thermal power plants. Appl Therm Eng 2010;30:2643-51.

[13] X. Py, N. Calvet, R. Olivès, P. Echegut, C. Bessada, F. Jay; "Thermal storage for solar power plants based on low cost recycled material". EFFSTOCK, the 11th International Conference on Thermal Energy Storage, June 14-17, 2009, Stockholm, Sweden

[14] The Ecoinvent Centre. A competence centre of ETH; PSI; Empa \& ART; http://www.ecoinvent.ch/. Ecoinvent data v2.1.

[15] Solaripedia <http://www. solaripedia.com/> last accessed on April 2014

[16] Hammond G, Jones C. Inventory of carbon \& energy (ICE) version 1.6a. University of Bath. 2008

[17] CES Selector 2012 software, Granta Design Limited, Cambridge, UK, 2012, (www.grantadesign.com).

[18] Hischier R, Weidema B, Althaus HJ, Bauer C, Doka G, Dones R, Frischknecht R, Hellweg S, Humbert S, Jungbluth N, Köllner T, Loerincik Y, Margni M, Nemecek T. Implementation of Life Cycle Impact Assessment Methods. (2010) Final report ecoinvent v2.2 No. 3. Swiss Centre for Life Cycle Inventories, Dübendorf, $\mathrm{CH}$.

[19] Arvidsson R, Fransson K, Fröling M, Svanström M, Molander S. Energy use methods in energy and life cycle assessments of biofuels: review and recommendations. J Cleaner Prod 2012;31:54-61. 


\section{Tables}

Table 1 Storage capacity and storage material used in each system considered, based on [10-13]

\begin{tabular}{|l|c|c|c|}
\hline & Solid system & Molten salts system & PCM system \\
\hline Storage capacity (kWh) & 350 & $600 \cdot 10^{3}$ & 100 \\
\hline $\begin{array}{l}\text { Storage material } \\
\text { Amount storage } \\
\text { material (kg) }\end{array}$ & $\begin{array}{c}\text { High temperature } \\
\text { concrete }\end{array}$ & $\begin{array}{c}60 \mathrm{wt} \% \mathrm{NaNO}_{3}+40 \\
\mathrm{wt} \% \mathrm{KNO}_{3}\end{array}$ & $\begin{array}{r}46 \mathrm{wt} \% \mathrm{NaNO}_{3}+ \\
54 \mathrm{wt} \% \mathrm{KNO}_{3}\end{array}$ \\
\hline $\begin{array}{l}\text { Storage capacity ratio } \\
(\text { MWh/kg) }\end{array}$ & $1.31 \cdot 10^{-5}$ & $5,500 \cdot 10^{3}$ & 2,100 \\
\hline $\begin{array}{l}\text { Storage material price } \\
(€ / \text { tonne) }\end{array}$ & 80 & $1.09 \cdot 10^{-4}$ & $4.76 \cdot 10^{-5}$ \\
\hline
\end{tabular}

Table 2 Solid system components with their quantity of material and their embodied energy value.

\begin{tabular}{|l|r|r|}
\hline Component & Amount used [10] & Embodied energy [14] \\
\hline Concrete & $1,037 \mathrm{~m}^{3}$ & $1,449 \mathrm{MJ} / \mathrm{m}^{3}$ \\
\hline Tubes of steel & $2,577,540 \mathrm{~kg}$ & $4 \mathrm{MJ} / \mathrm{kg}$ \\
\hline High temperature concrete & $16,490 \mathrm{~m}^{3}$ & $1,449 \mathrm{MJ} / \mathrm{m}^{3}$ \\
\hline Metal sheets & $24,955 \mathrm{~kg}$ & $6 \mathrm{MJ} / \mathrm{kg}$ \\
\hline Rock wool & $58,032 \mathrm{~kg}$ & $22 \mathrm{MJ} / \mathrm{kg}$ \\
\hline
\end{tabular}


Table 3 Molten salts system components with the quantity of material and embodied energy value.

\begin{tabular}{|l|r|r|}
\hline Component & Amount used [11] & Embodied energy [14] \\
\hline $\mathrm{KNO}_{3}$ & $3,300,000 \mathrm{~kg}$ & $16 \mathrm{MJ} / \mathrm{kg}$ \\
\hline $\mathrm{NaNO}_{3}$ & $2,200,000 \mathrm{~kg}$ & $16 \mathrm{MJ} / \mathrm{kg}$ \\
\hline Concrete & $552 \mathrm{~m}^{3}$ & $1,449 \mathrm{MJ} / \mathrm{m}^{3}$ \\
\hline Poor concrete & $236 \mathrm{~m}^{3}$ & $802 \mathrm{MJ} / \mathrm{m}^{3}$ \\
\hline Stainless steel & $3,361 \mathrm{~m}^{2}$ & $21 \mathrm{MJ} / \mathrm{m}^{2}$ \\
\hline Firebricks & $1,271,757 \mathrm{~kg}$ & $20 \mathrm{MJ} / \mathrm{kg}$ \\
\hline Carbon steel & $554,053 \mathrm{~kg}$ & $6 \mathrm{MJ} / \mathrm{kg}$ \\
\hline Ceramic fibre & $10,420 \mathrm{~kg}$ & $10 \mathrm{MJ} / \mathrm{kg}$ \\
\hline Aluminium sheet & $1,548 \mathrm{~m}^{2}$ & $67 \mathrm{MJ} / \mathrm{m}^{2}$ \\
\hline Sand & $417,726 \mathrm{~kg}$ & $<1 \mathrm{MJ} / \mathrm{kg}$ \\
\hline Foamglass & $4,256 \mathrm{~kg}$ & $36 \mathrm{MJ} / \mathrm{kg}$ \\
\hline Molten salt pump & $2 \mathrm{units}$ & $1,560,141 \mathrm{MJ} / \mathrm{u}$ \\
\hline Water pump & $30 \mathrm{units}$ & $119 \mathrm{MJ} / \mathrm{u}$ \\
\hline
\end{tabular}

Table 4 PCM system components with the quantity of material and embodied energy value.

\begin{tabular}{|l|r|r|}
\hline Component & Amount used [12] & Embodied energy [14] \\
\hline Concrete & $518 \mathrm{~m}^{3}$ & $1,449 \mathrm{MJ} / \mathrm{m}^{3}$ \\
\hline Tubes of steel & $1,214,520 \mathrm{~kg}$ & $4 \mathrm{MJ} / \mathrm{kg}$ \\
\hline Metal sheets & $138,455 \mathrm{~kg}$ & $6 \mathrm{MJ} / \mathrm{kg}$ \\
\hline $\mathrm{KNO}_{3}$ & $6,804,000 \mathrm{~kg}$ & $16 \mathrm{MJ} / \mathrm{kg}$ \\
\hline $\mathrm{NaNO}_{3}$ & $5,796,000 \mathrm{~kg}$ & $16 \mathrm{MJ} / \mathrm{kg}$ \\
\hline Aluminium sheets & $26,137 \mathrm{~kg}$ & $6 \mathrm{MJ} / \mathrm{kg}$ \\
\hline Rock wool & $16,171 \mathrm{~kg}$ & $22 \mathrm{MJ} / \mathrm{kg}$ \\
\hline Foamglass & $22,473 \mathrm{~kg}$ & $36 \mathrm{MJ} / \mathrm{kg}$ \\
\hline
\end{tabular}


Table 5 Components and their corresponding Ecoinvent database name [14].

\begin{tabular}{|c|c|}
\hline Component & $\begin{array}{l}\text { Corresponding database name, [equivalent unit] (code } \\
\text { number) }\end{array}$ \\
\hline Concrete & Concrete, normal, at plant $\left[\mathrm{m}^{3}\right]$ (\#504) \\
\hline Tubes of steel & Drawing of pipes, steel $[\mathrm{kg}](\# 1163)$ \\
\hline $\begin{array}{l}\text { High temperature } \\
\text { concrete }\end{array}$ & Concrete, normal, at plant $\left[\mathrm{m}^{3}\right]$ (\#504) \\
\hline Metal sheets & Sheet rolling, steel [kg] (\#1174) \\
\hline Rock wool & Rock wool, packed, at plant [kg] (\#1001) \\
\hline Foamglass ${ }^{\circledR}$ & Foam glass, at plant [kg] (\#7160) \\
\hline KNO3 & Potassium nitrate, as N, at regional storehouse (\#52) \\
\hline NaNO3 & Sodium nitrate, as N, at regional storehouse [kg] (\#52) \\
\hline $\begin{array}{l}\text { Stainless steel (metal } \\
\text { sheets) }\end{array}$ & Selective coating, stainless steel sheet, black chrome $\left[\mathrm{m}^{2}\right]$ (\#1189) \\
\hline Firebricks & Refractory, fireclay, packed, at plant [kg] (\#498) \\
\hline Carbon steel & Sheet rolling, steel $[\mathrm{kg}](\# 1174)$ \\
\hline Ceramic fiber & Cellulose fibre, inclusive blowing in, at plant [kg] (\#991) \\
\hline Aluminum sheet & Powder coating, aluminium sheet $\left[\mathrm{m}^{2}\right]$ (\#1166) \\
\hline Sand & Silica sand, at plant [kg] (\#479) \\
\hline Poor concrete & Poor concrete, at plant $\left[\mathrm{m}^{3}\right](\# 511)$ \\
\hline Carbon steel & Sheet rolling, steel $[\mathrm{kg}](\# 1174)$ \\
\hline Molten salt pump & Pump station [unit] (\#5736) \\
\hline Water pump & Pump 40 W, at plant [unit] (\#1865) \\
\hline Disposal concrete & Disposal, building, concrete, not reinforced, to recycling [kg] (\#2148) \\
\hline $\begin{array}{l}\text { Disposal concrete }+ \\
\text { steel bars }\end{array}$ & Disposal, building, reinforced concrete, to recycling $[\mathrm{kg}]$ (\#2153) \\
\hline Disposal Metal sheets & Disposal, steel, 0\% water, to inert material landfill [kg] (\#2082) \\
\hline Disposal rock wool & $\begin{array}{l}\text { Disposal, insulation spiral-seam duct, rock wool, DN 400, } 30 \mathrm{~mm}[\mathrm{~m}] \\
(\# 10,825)\end{array}$ \\
\hline Disposal foamglass ${ }^{\circledR}$ & $\begin{array}{l}\text { Disposal, insulation spiral-seam duct, rock wool, DN } 400,30 \mathrm{~mm}[\mathrm{~m}] \\
(\# 10,825)\end{array}$ \\
\hline Disposal KNO3 & $\begin{array}{l}\text { Disposal, salt tailings potash mining, } 0 \% \text { water, to residual material } \\
\text { landfill }[\mathrm{kg}](\# 2202)\end{array}$ \\
\hline Disposal NaNO3 & $\begin{array}{l}\text { Disposal, salt tailings potash mining, } 0 \% \text { water, to residual material } \\
\text { landfill }[\mathrm{kg}](\# 2202)\end{array}$ \\
\hline Disposal stainless steel & Disposal, steel, 0\% water, to inert material landfill [kg] (\#2082) \\
\hline Disposal firebricks & Disposal, refractory SPL, Al elec.lysis, $0 \%$ water, to residual material \\
\hline
\end{tabular}




\begin{tabular}{|l|l|}
\hline & landfill [kg] (\#2200) \\
\hline Disposal Carbon steel & Disposal, steel, 0\% water, to inert material landfill [kg] (\#2082) \\
\hline Disposal ceramic fibre & Disposal, building, fibre board, to final disposal [kg] (\#2016) \\
\hline Disposal aluminium & Disposal, aluminium, 0\% water, to sanitary landfill [kg] (\#2215) \\
\hline Disposal sand & $\begin{array}{l}\text { Disposal, slag from MG silicon production,0\% water, to inert material } \\
\text { landfill [kg] (\#2081) }\end{array}$ \\
\hline Disposal poor concrete & Disposal, building, concrete, not reinforced, to recycling [kg] (\#2148) \\
\hline Disposal of tubes & Disposal, steel, 0\% water, to inert material landfill [kg] (\#2082) \\
\hline
\end{tabular}

Table 6 Some of the environmental methods available in the Ecoinvent database, based on [15].

\begin{tabular}{|l|l|l|l|}
\hline Method & $\begin{array}{l}\text { I mpact } \\
\text { category }\end{array}$ & Unit & Application \\
\hline $\begin{array}{l}\text { Ecological } \\
\text { footprint }\end{array}$ & - & $\mathrm{m}^{2} \mathrm{a}$ & Global \\
\hline EDIP 2003 & Global warming & $\mathrm{kg} \mathrm{CO}_{2}-\mathrm{Eq}$ & Global \\
\hline TRACl & Global warming & $\mathrm{kg} \mathrm{CO}_{2}$-Eq & Global \\
\hline CED & - & $\mathrm{MJ}$ & Global \\
\hline
\end{tabular}

Table 7 Resources included in the different energy sources [18]

\begin{tabular}{|l|l|l|}
\hline \multirow{2}{*}{$\begin{array}{l}\text { Non- } \\
\text { renewable } \\
\text { resources }\end{array}$} & Subcategory & Includes \\
\cline { 2 - 3 } & Fussil & $\begin{array}{l}\text { Hard coal, lignite, crude oil, natural gas, coal mining off-gas, } \\
\text { peat }\end{array}$ \\
\cline { 2 - 3 } & Primary forest & Uranium \\
\hline \multirow{3}{*}{$\begin{array}{l}\text { Renewable } \\
\text { resources }\end{array}$} & Wiomass & Wood, food products, biomass from agriculture, e.g. straw \\
\cline { 2 - 3 } & Wind & Wind energy \\
\cline { 2 - 3 } & Solar & Solar energy (used for heat and electricity) \\
\cline { 2 - 3 } & Geothermal & Geothermal energy \\
\cline { 2 - 3 } & Water & Run-of-river hydro power, reservoir hydro power \\
\hline
\end{tabular}




\section{Figures}

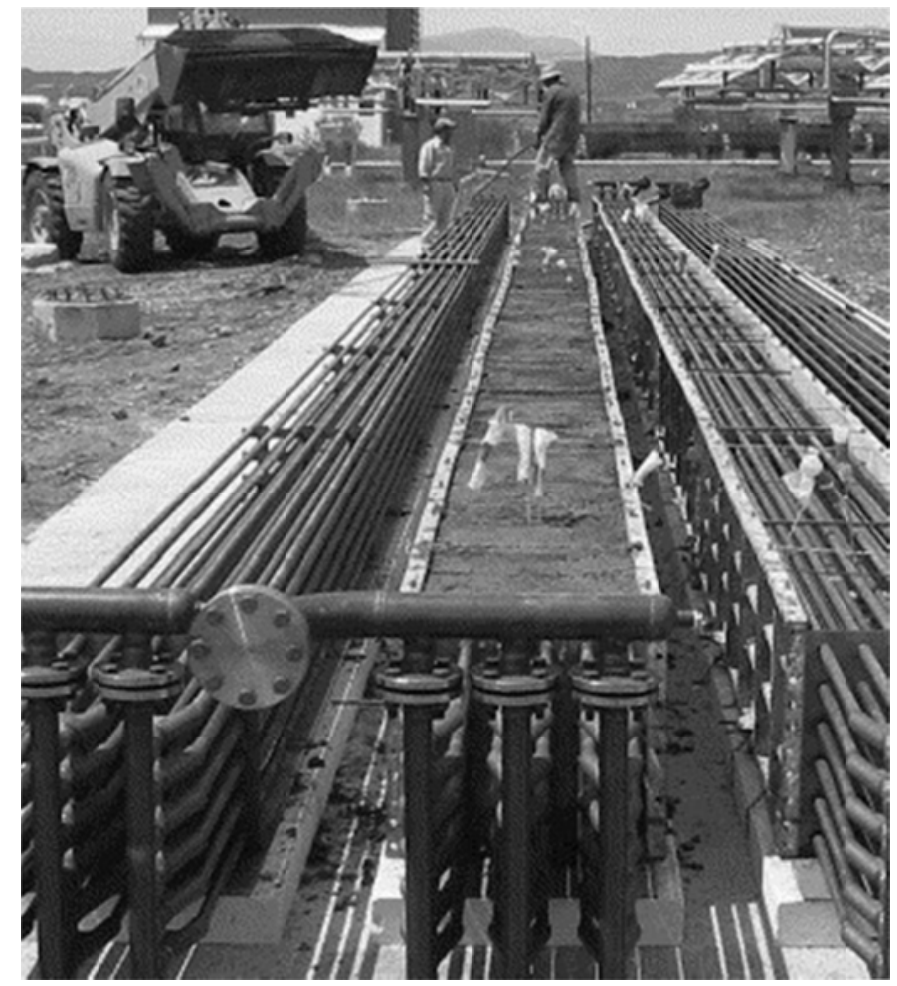

Figure 1 Solid storage system [10].

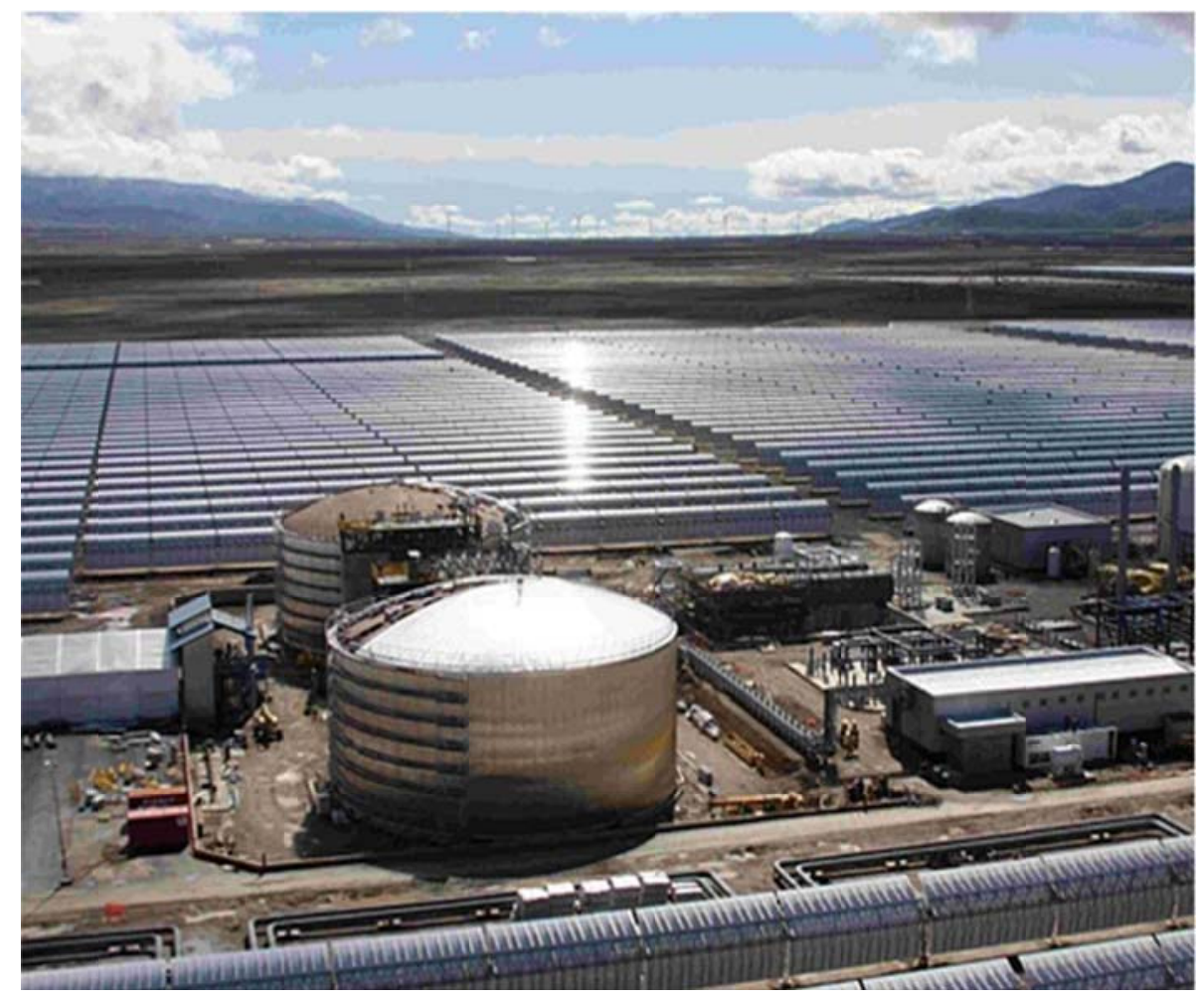

Figure 2 Molten salts storage system [15]. 
a TES module top view

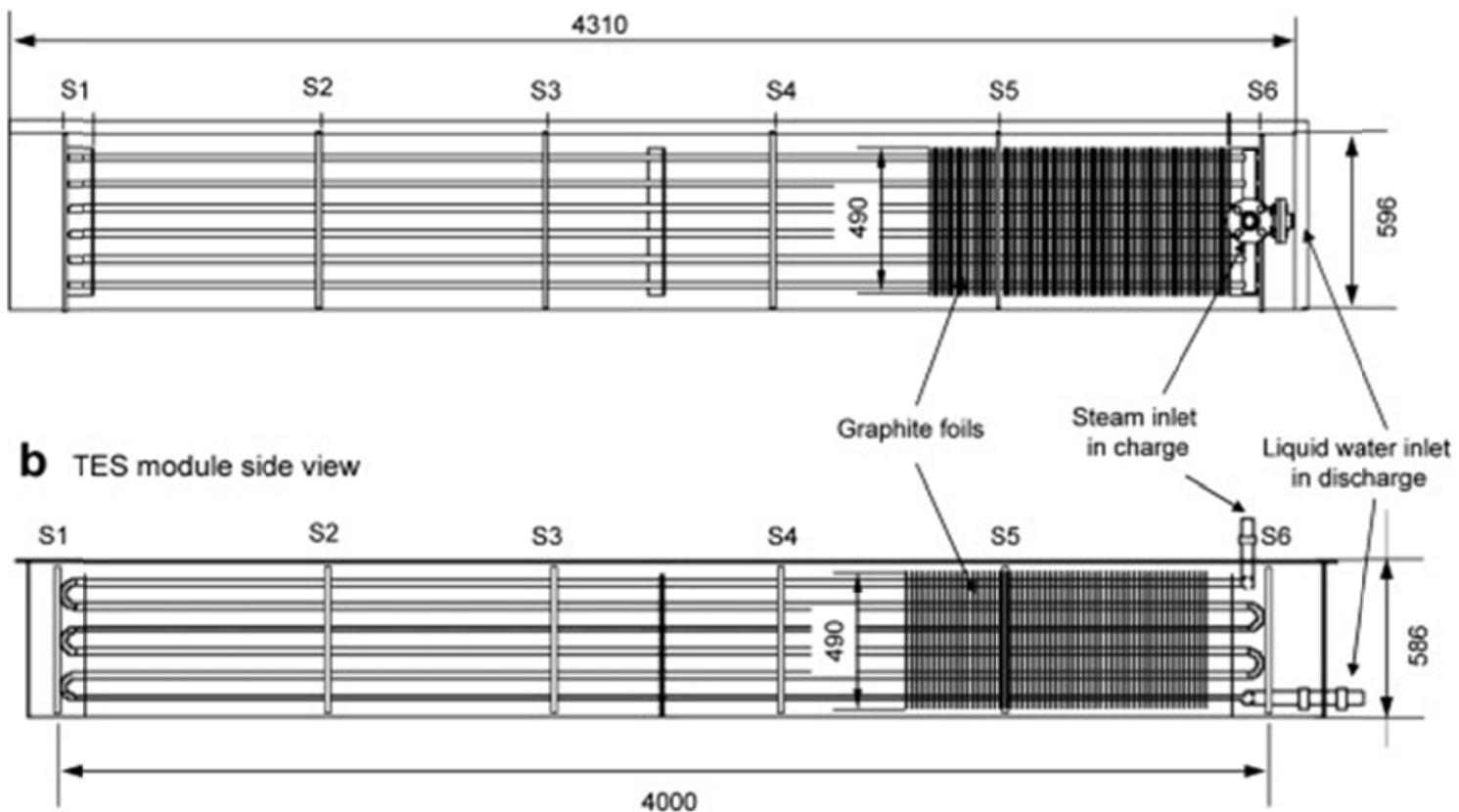

Figure 3 PCM storage system [12].

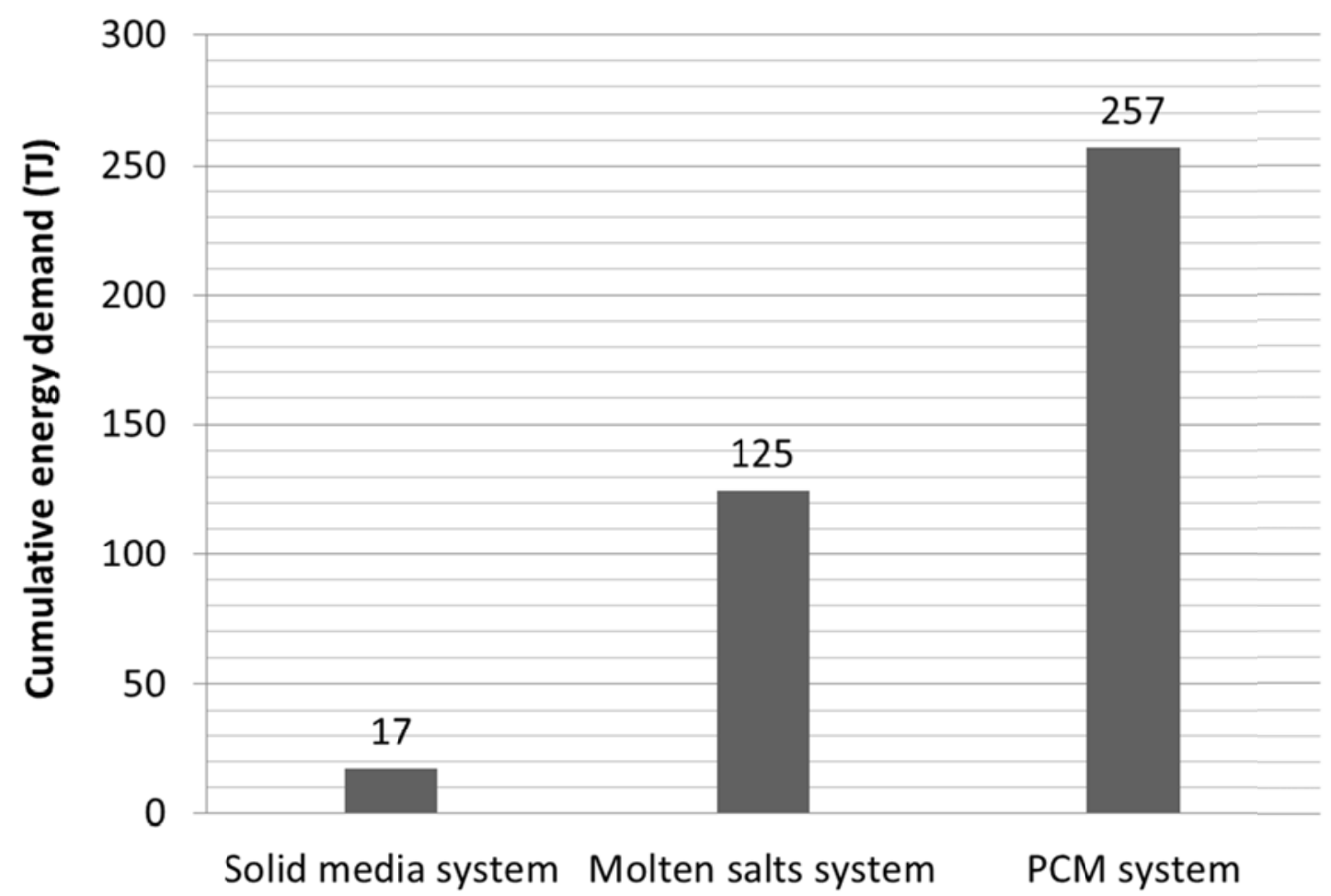

Figure 4 Total embodied energy for the three storage systems. 

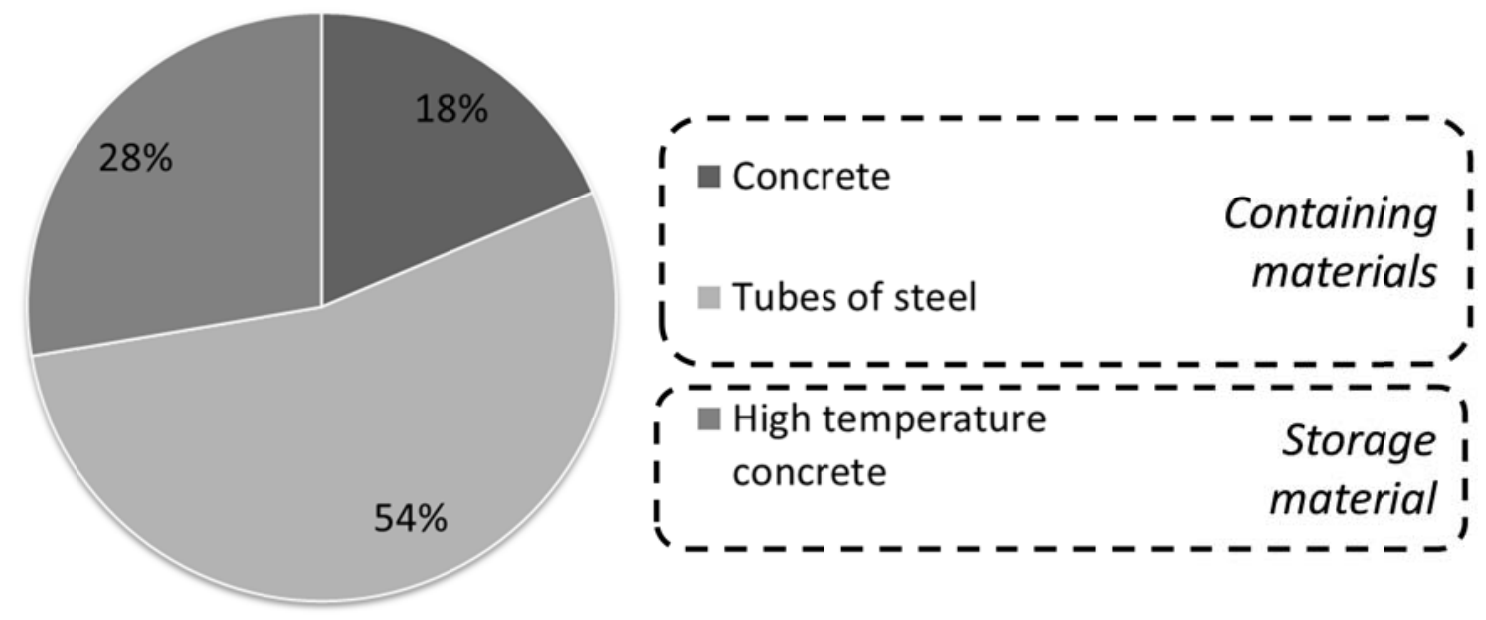

Figure 5 Distribution of the embodied energy most influencing components of the solid system.
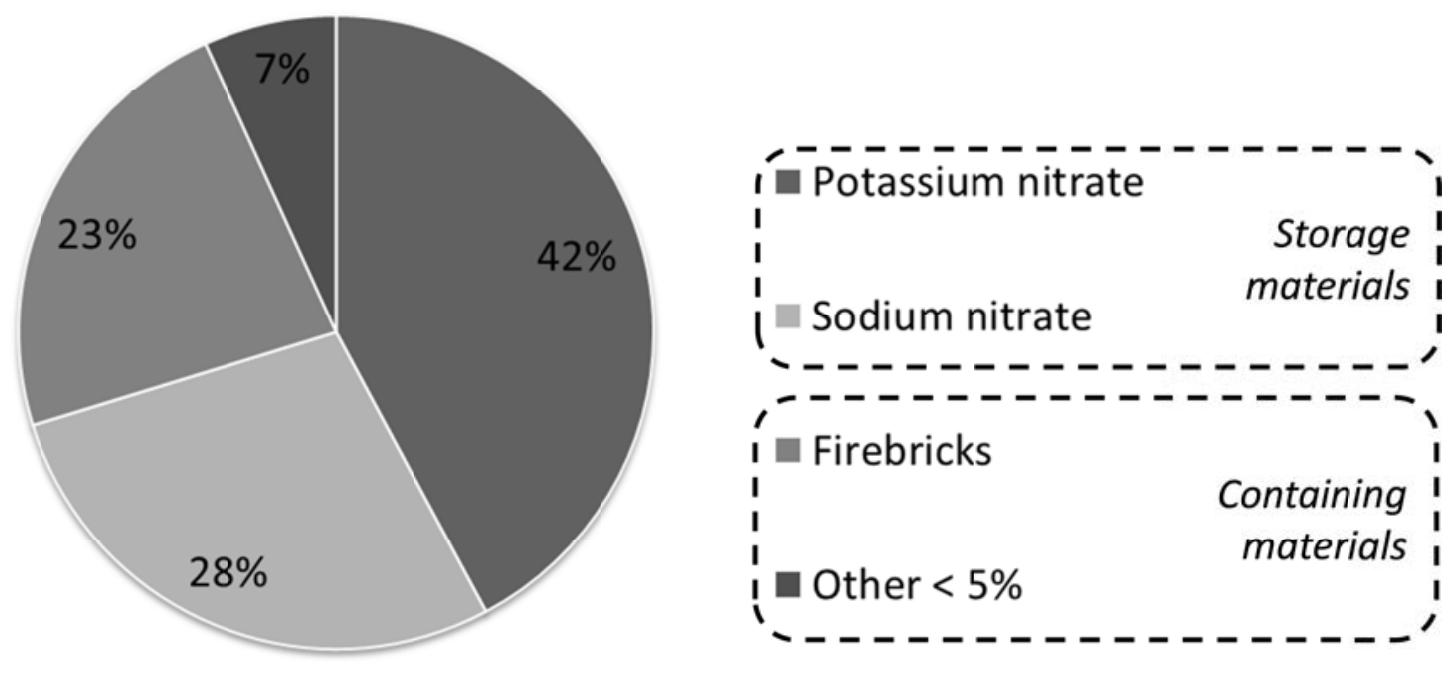

Figure 6 Distribution of the embodied energy most influencing components of the molten salts system ("Other < 5 \%" includes all the components that affect less than $5 \%$ in the total distribution). 


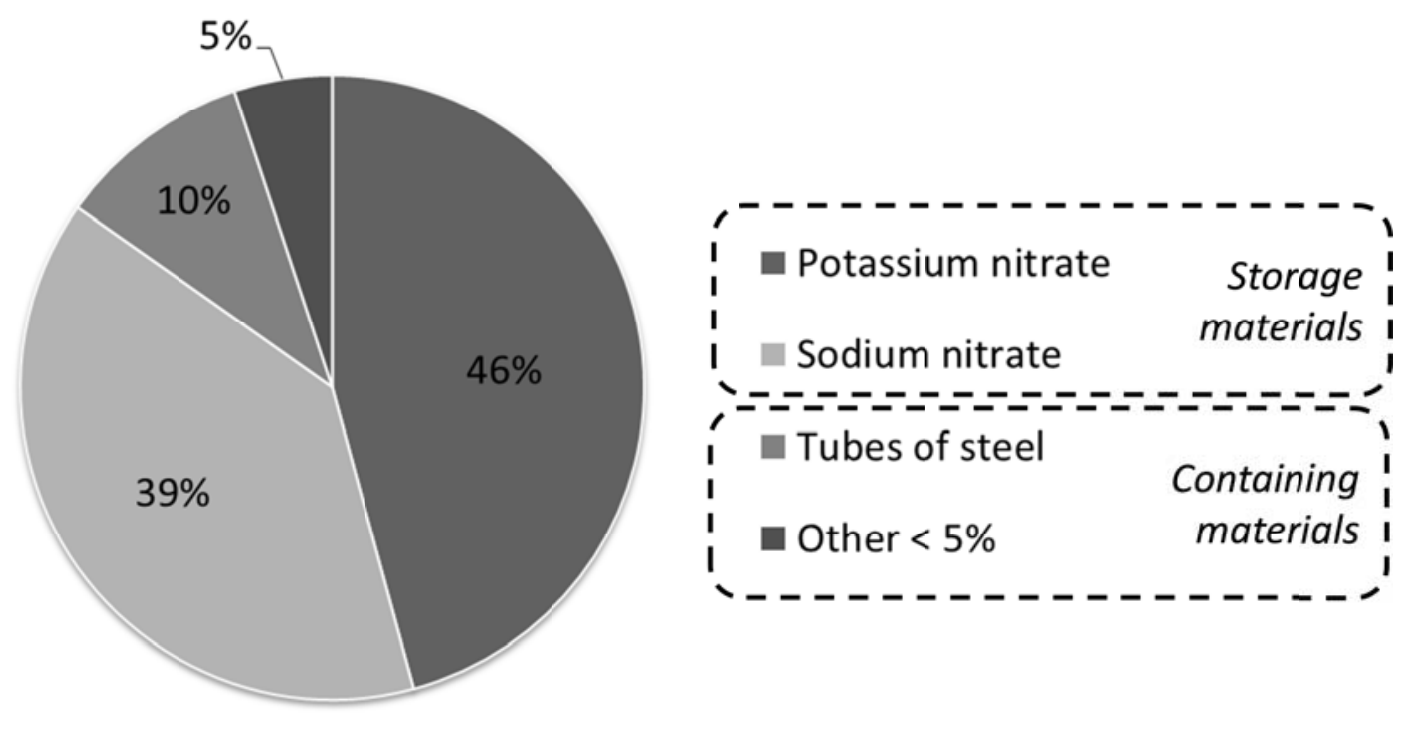

Figure 7 Distribution of the embodied energy most influencing components of the PCM system ("Other < $5 \%$ \% includes all the components that affect less than $5 \%$ in the total distribution).

CED containing material $\quad$ CED storage material

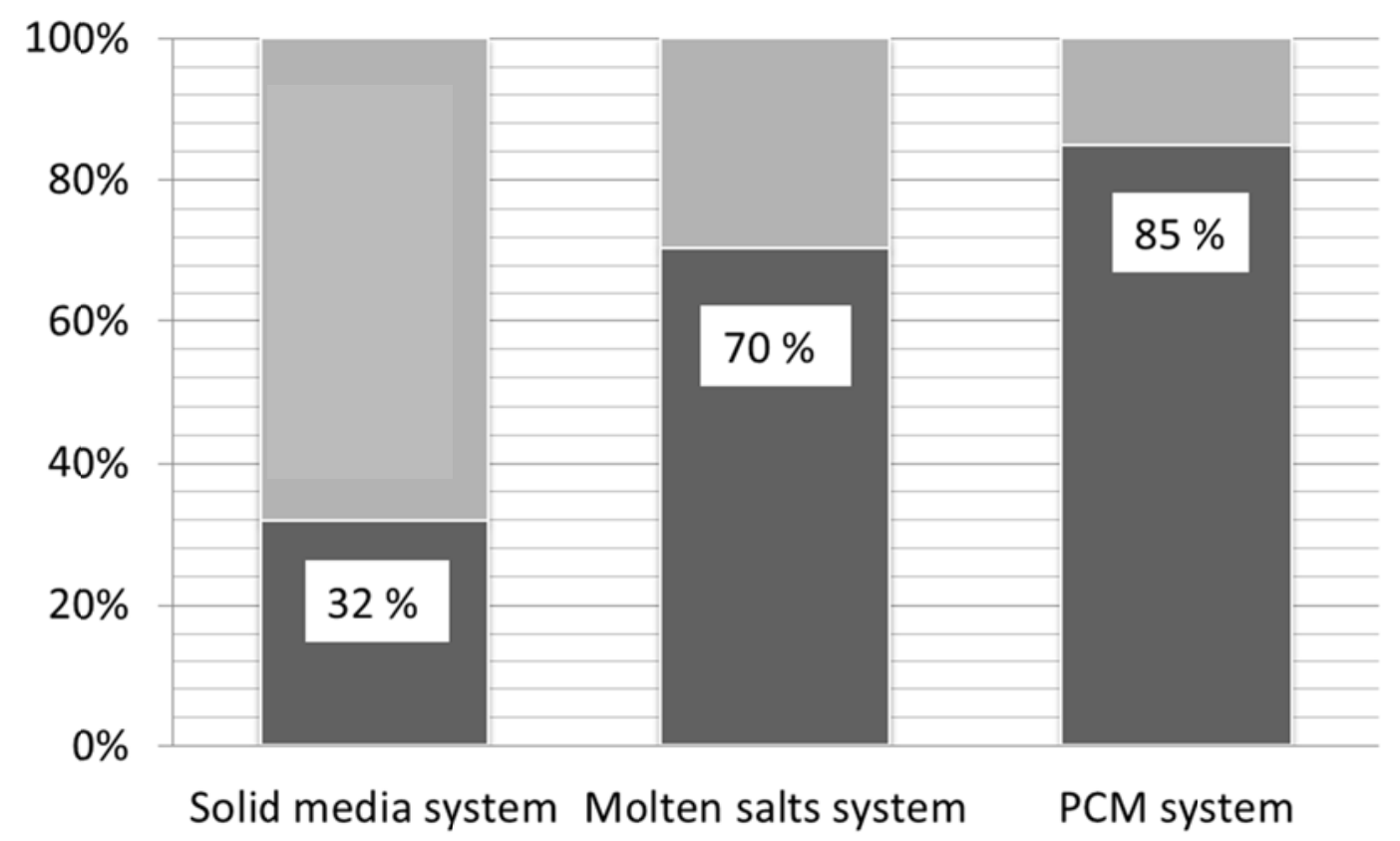

Figure 8 Influence of storage materials and container embodied energy for the three systems. 